\title{
May Christians request medically assisted suicide and euthanasia?
}

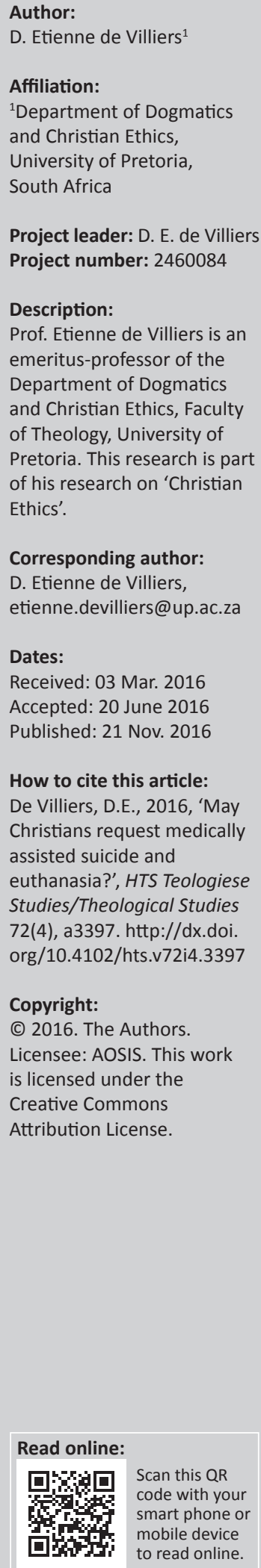

The article deals with the question: 'Is it morally acceptable for terminally ill Christians to voluntarily request medically assisted suicide or euthanasia?' After a brief discussion of relevant changes in the moral landscape over the last century, two influential, but opposite views on the normative basis for the Christian ethical assessment of medically assisted suicide and voluntary euthanasia are critically discussed. The inadequacy of both the view that the biblical message entails an absolute prohibition against these two practices, and the view that Christians have to decide on them on the basis of their own autonomy, is argued. An effort is made to demonstrate that although the biblical message does not entail an absolute prohibition it does have normative ethical implications for deciding on medically assisted suicide and voluntary euthanasia. Certain Christian beliefs encourage terminally ill Christians to live a morally responsible life until their death and cultivate a moral prejudice against taking the life of any human being. This moral prejudice can, however, in exceptional cases be outweighed by moral considerations in favour of medically assisted suicide or voluntary euthanasia.

\section{Introduction}

The debate on the legalising of medically assisted suicide and euthanasia in the South African society has significantly intensified over the last few years. There is no reason to believe that it will subside in the near future.

The reason being, first of all, that even in a developing country like South Africa the rapid advance in medical science and technology has drastically changed the nature of the dying process for a significant number of people. Modern medicine has in most countries eliminated viral diseases as the prime cause of death. Even if it is true that in South Africa HIV or Aids is still a prime cause of death, a large percentage of the population die of illnesses like cancer, heart disease, stroke and the complications of diabetes. Where viral diseases in the past resulted in a relatively quick death for most people, the dying process in the case of the above mentioned diseases is mostly a prolonged one, often involving very high medical costs and intense suffering. More and more family members and friends witnessing the prolonged and intense suffering of their loved ones would like to have the option to request medically assisted suicide or euthanasia should they find themselves in the same situation (cf. Badham 2009:5-19; Kuitert 1993:29-34).

There is, however, another reason. More and more people in South Africa, including Christians, are inadvertently influenced by the liberal value of individual autonomy. ${ }^{1}$ They are no longer willing to leave decisions on medical procedures administered to them entirely in the hands of medical experts, especially not when these procedures will most likely lead to the prolongation and intensification of their own suffering. And when it becomes clear that their death is imminent as a result of terminal illness they want to have a say regarding the time and manner in which they depart from this life.

In the present debate on medically assisted suicide and euthanasia the issue of legalisation dominates. ${ }^{2}$ The more personal question of whether Christians should regard medically assisted suicide and euthanasia as morally acceptable and as a result also promote and personally request it, plays a secondary role. It is a pity, as the issue of the moral acceptability of these two practices is, in my opinion, in certain respects more basic and important than the issue of their legalisation. 1.See for the growth in personal autonomy in the Western world over the last 200 years Paul Badham (2009:16-17).

2.The reason being that effective campaigns of pro-euthanasia organisations (in South Africa especially Dignity South Africa) and conspicuous court cases in which terminally ill patients apply for legal permission to undergo medically assisted suicide or euthanasia are well publicised. 
Although the two issues of the moral acceptability and the legalisation of medically assisted suicide and euthanasia are decided on different sets of arguments, one can hardly support the legalisation of the two practices when one is of the opinion that they are absolutely wrong from a moral perspective. Although it is true that the implementation of the personal conviction that the two practices are morally acceptable would only be possible when they are legalised, their legalisation does not necessarily entail their moral acceptability. Should medically assisted suicide and euthanasia be legalised in South Africa we who are Christians would still have to decide whether we personally support the two practices from a moral perspective.

It is not possible within the scope of one article to deal adequately with all the aspects involved with the question: 'What view should Christians have on the moral acceptability of medically assisted suicide and euthanasia?' To deal adequately with this question one has to pay attention not only to medically assisted suicide (per definition voluntary in nature) and voluntary euthanasia, but also to non-voluntary and involuntary euthanasia in the case of severely handicapped infants, patients in a permanent coma (persistent vegetative state) and older people with advanced dementia or Alzheimer's. ${ }^{3}$ One would also have to deal with the ethical issues different role players are confronted with: the suffering and terminally ill patient, the patient's next-of-kin and the medical personnel responsible for assisting the patient in committing suicide or administrating the injection resulting in euthanasia. In this article the attention will be solely directed to the question: 'Is it morally acceptable for terminally ill Christians to voluntarily request medically assisted suicide or euthanasia?'

The argument will be developed in four steps. Firstly, a brief sketch is provided of relevant changes in the moral landscape over the last century which Christians will have to take account of when deciding on medical ethical issues. Secondly, two extreme and opposite contemporary views are critically discussed:

- the view that Christians should morally reject medically assisted suicide and euthanasia on account of the absolute proscription against such practices entailed in the message of the Bible

- the view that Christians, like non-Christians, have to decide on these two practices on the basis of their own autonomy, as distinctive Christian beliefs do not provide any relevant moral guidance, but at the most have some motivational value.

Thirdly, the moral implications of relevant Christian beliefs for deciding on the moral acceptability of requesting medically assisted suicide and euthanasia are discussed.

3.With Michael Banner one may ask whether the issue of medically assisted suicide and voluntary euthanasia in the case of terminally ill persons does not today get too much public attention, while the 'death before death' of a growing number of elderly people is to a large extent neglected. In his book The ethics of everyday life he points out: According to current expectations, maybe only 20 per cent of us can expect a clearly heralded death as commonly occurs with cancer-but fully twice as many will experience not a clearly marked dying, but a protracted 'dwindling' of increasing debility... For very many of the 40 per cent of us who will have a lon dying our declines will also be marked by dementia. Figures vary, but in the olde cohorts of the dwindling, perhaps as many as $15 \%-20 \%$ are predicted to experience some form of dementia, typically Alzheimer's' (Banner 2014:118).
Fourthly, some conclusions are drawn on the stance Christians ought to take when they are faced with the option of seeking medically assisted suicide or euthanasia.

\section{The changed moral landscape}

Already at the beginning of the twentieth century the German sociologist Max Weber explained Western modernity as the outcome of unique rationalisation processes that, amongst others, undermined the dominance of Christian ethics in Western societies. The demise of the public influence of Christian ethics went hand in hand with an increase in the plurality of ethical systems, vying with one another for recognition, and the differentiation of different social spheres, each with its own distinctive set of non-moral values those operating within these spheres have to recognise (cf. Whimser 2004:215-226). These developments also have an influence on Christians and the moral beliefs they adhere to. Not only do contemporary Christians adhere to different sets of Christian moral beliefs on account of the proliferation of Christian confessions and denominations, but do they also to different extents take over and internalise values from liberalism, as the dominant life view in the Western world (e.g. autonomy), as well as from capitalism, as the dominant Western economic system (e.g. consumerist attitudes).

It has, however, not only been the master narrative of Christianity and Christian ethics that came under fire in the twentieth century. Postmodern thinkers also increasingly criticised the master narrative of the Enlightenment and the claims of Enlightenment thinkers such as Immanuel Kant and John Stewart Mill to have provided a rational and universal foundation for morality. Many philosophers today agree that no universally accepted rational foundation for morality can be found. We as individuals have to fall back for our own moral decisions on the personal moral beliefs we have gained and internalised by means of moral education and bricolage, that is, intentionally or unintentionally selecting specific moral tenets from different traditions, and integrating them into our existing sets of moral beliefs. ${ }^{4}$ Our personal moral belief systems, which can range from conforming almost completely to the moral belief system of a particular religious or cultural group, to being highly individualistic and unique, provide the major ethical framework for our attitudes and actions. The important role particular moral traditions continue to play as a source in personal moral decision-making has led to the reaffirmation of the authority and validity of such moral traditions by influential philosophers and theologians. A philosopher like Alasdair MacIntyre and a theologian like Stanley Hauerwas unashamedly defend the authority and validity of particular moral traditions, Aristotelian virtue ethics in the case of MacIntyre and Christian virtue ethics in the case of Hauerwas (cf. Hauerwas 1981; MacIntyre 1984).

4. Jeffrey Stout understands bricolage in the context of morality as' a process in which the them into a language ready to use, possibly a quite new one' (Stout 1988:74). In his opinion 'we are all bricoleurs, insofar as we are capable of creative thought at all' (Stout 1988:74) 
Part of the critical response of postmodern philosophers and theologians to Enlightenment ethics relates to the one-sided emphasis on actions and the principles and norms that guide actions. This same one-sided emphasis can, according to Hauerwas, also be found in contemporary Christian ethics and especially Protestant ethics. Already in a collection of some of his early articles, entitled Vision and virtue (1974) he voiced his criticism: 'When ethics is limited to an analysis of the justification for particular actions, then it is indeed difficult to make sense of Christian ethics. The language of the Gospel includes, but points beyond, judgments about particular actions and practices to the nature of the self and how it is formed for our life projects. Once ethics is focused on the nature and moral determination of the self, vision and virtue again become morally significant categories' (Hauerwas 1974:1-2; cf. also 1983:71). What we gain with a more comprehensive understanding of Christian ethics, which apart from norms for action, also includes visions on goals to be realised and virtues to be cultivated, is that the inextricable relation between Christian dogmatic and ethical beliefs, and the distinctive nature of Christian ethics are more easily demonstrated than in the case of a narrow understanding of Christian ethics in terms of principles and norms for action alone (De Villiers 2012:5). There is in my opinion an added advantage, namely that such a comprehensive understanding of Christian ethics allows a more flexible approach to ethical decision-making when we are confronted with difficult ethical decisions on, for example, medically assisted suicide and euthanasia. Having a Christian vision of life and exhibiting Christian virtues, no doubt entails a preference for certain options for action, and a prejudice over against others, but does not necessarily imply that only one particular option for action is morally right and all the other options wrong.

Closely related to the last remark on flexibility in Christian ethics is the criticism expressed by Max Weber in his famous speech 'Politics as a vocation' on the approach to ethical decision-making he indicated by the name 'ethic of conviction' (Gesinnungsethik). What he had in mind with the 'ethic of conviction' approach in ethics was the absolutist manner in which certain politicians of his time advocated a particular action or policy as the morally right one, ignoring the fact that they are operating within the political sphere and in a particular historical situation, and without taking any foreseeable negative consequences into account. Among others, he had in mind radical Christian pacifist politicians who refused to support any use of violence by the government. As an alternative more acceptable, approach to ethical decision-making, Weber proposed the 'ethic of responsibility' (Verantwortungsethik). Different from the politician following the ethic of conviction approach, the politician following the ethic of responsibility approach would take into account that non-moral values, apart from moral ones, are also valid in the political sphere, would respect the concrete, historical situation of decision-making and would acknowledge the foreseeable consequences of different options for action before deciding on a particular action (Weber 1994:309-369). In my opinion, the ethic of responsibility approach has been affirmed in ethical thought since the early twentieth century. The absolutist and abstract approach of both Enlightenment and Christian duty ethics in which one particular indubitable moral principle is applied in an identical manner to all situations has been discredited. We cannot but acknowledge today that the situation of ethical decision-making to a large extent determines the mix of moral and non-moral norms on the basis on which decisions are made. The different and often conflicting demands involved with such a set of moral and non-moral norms have to be weighed up, but also the foreseeable consequences of different options for action. We are often faced with moral dilemmas and in many cases compromises are unavoidable. As a result, the claim that the option for action we support is absolutely right, while all the others are absolutely wrong, is for the most part unjustified. We even often have to admit that the action we prefer is at the most the better of two moral wrongs.

\section{Two extreme contemporary Christian views}

In contemporary Christian ethical literature the debate on medically assisted suicide and euthanasia is often portrayed as one between protagonists of the view that the biblical message entails an absolute rejection of both these practices and the view that even Christians have to autonomously decide on them, as the Bible does not really provide moral guidance in this regard (cf. Kuitert 1993; Meilaender 1996). There is also the tendency to oversimplify by holding up one of these extreme views as the only cogent alternative for those who want to avoid adherence to the 'intolerable' view on the opposite side. A closer look at the views and the arguments used in supporting them reveals this oversimplification.

\section{The message of the Bible entails an absolute prohibition}

According to Michael Friess, Christians mostly base an absolute prohibition of medically assisted suicide and euthanasia on the sixth commandment: 'Thou shalt not kill' and the belief that God is the Lord over life and death. When one analyses the sixth commandment and the belief in the Almighty God's lordship, however, it in Friess's opinion soon becomes clear that neither of them entails such an absolute prohibition (Friess 2012a:26-35).

In the case of the sixth commandment it is conspicuous that a very specific Hebrew verb is used, namely one that refers to blood revenge against a fellow Israelite, but not to the killing of someone in war or by means of capital punishment. For this reason most Old Testament scholars argue that the sixth commandment should rather be translated: 'Thou shalt not murder'. What is, according to them, prohibited by the sixth commandment is not killing as such, as the Old Testament endorses capital punishment for quite a number of transgressions and war against enemies of Israel, but illegitimate killing. Seemingly the nine cases of suicide reported in the Old Testament were also not regarded as 
illegitimate killing, as no negative comments against any of the suicides can be traced. The suicide of Samson is even portrayed as an act of heroism.

That what counts as legitimate or illegitimate killing depends on different interpretations and circumstances, has been demonstrated in the history of Christianity. On account of Jesus's radical interpretation of the ethical implications of the love commandment for the use of violence in the Sermon on the Mount, and in response to the conscription of Christian men for military service, the early church, on the one hand, proclaimed pacifism. Christians refused to serve in the Roman army as that, among others, meant that they would have to kill other human beings. On the other hand, suicide by believers in certain situations of severe persecution was not condemned when committed, for example, to avoid succumbing to apostasy or being raped by Roman soldiers and lose one's virginity (Badham 2009:37).

After Constantine in 312 introduced Christianity as the official religion of the Roman Empire and Christians participated in government, the radical pacifist stance of the early Christian church was abolished. The theologian Augustine developed a Christian version of the just war doctrine in his The city of God (2004), which declared the killing of soldiers in defence of the Roman Empire ethically legitimate. Interestingly enough he also in The city of God (I, 17-27) formulated the first comprehensive Christian ethical rejection of suicide, among others, using the argument that the sixth commandment entails a prohibition against the killing of all innocent persons, and thus by implication also against taking one's own life. An added argument was that suicide is absolutely wrong on account of the fact that it robs the responsible person of any opportunity to confess the deadly sin committed (cf. for a discussion of Augustine's view on suicide see Friess 2012b:31).

The Augustinian view that all killing of innocent people, and thus also suicide, is absolutely wrong remained dominant in the Christian church until quite recently. However, during the last century or more, Christian ethicists in especially Protestant circles have increasingly questioned the absolute rejection of all suicide. Lewis B Smedes, for example, pointed out that the first assumption on which such a rejection is based, namely that eternal salvation is dependent on the opportunity to do confession for deadly sins, flies in the face of the central biblical message on the infinite grace of God. Apart from that, empirical research on the causes of suicide has revealed that the majority of people do not commit suicide after due consideration and in deliberate defiance of God's commands, but are driven to it by severe mental illness or extremely traumatic experiences (cf. Smedes 1983:111-118). Developments in especially medical science and care have also in other respects brought the absolute Christian ethical doctrine that all killing of innocent persons is wrong, under pressure. The introduction of safe medical procedures in doing abortions has not only brought the issue of the legalisation of abortion to the forefront, but has also challenged ethicists, including Christian ethicists, to reflect on the question: 'Is abortion in certain cases ethically permissible?' Most Christian ethicists would today answer this question in the affirmative, although they would disagree on which cases are morally permissible. This means that most of them accept that in certain circumstances when we are faced with a moral dilemma, for example, between the moral obligation to save the life of the pregnant woman and the one to save the life of the foetus, it is morally permissible from a Christian ethical perspective to take innocent human life. The extension of the dying process on account of progress in medical care, now again raises the question: Would it not in certain circumstances be ethically justified for a terminally ill patient to request assisted suicide or euthanasia, or for others to grant this request? To be more specific: should not ethical considerations regarding these two practices based on the love commandment override the traditional Christian ethical conviction based on the sixth commandment when a terminally ill patient suffers unbearably and nothing can be done to relieve the pain and suffering?

The other Christian belief on which the absolute prohibition of medically assisted suicide and voluntary euthanasia is often based is that God Almighty is Lord over life and death. As Nigel Biggar rightly points out: there is a certain ambiguity with regard to the appeal to this Christian belief when it comes to the rejection of the named practices (Biggar 2004:105). It could be interpreted either to say that God alone may authorise the killing of a human being, or to say that only God has control over and may have control over the life and death of a human being. Should the first interpretation be taken as point of departure, we are confronted with the same basic issue we have already addressed in our discussion of the implications of the sixth commandment: What is the moral will of God in specific situations? It seems that even deciding on which biblical commandments or principles are applicable depends on our analysis of the situation. We are often confronted with a moral dilemma when two or more applicable commandments or principles seem to prescribe different and even contradictory actions. There is no way in which we can escape our responsibility to weigh up the different and seemingly contradictory implications and make a decision on the better of the different options for action. That is not to deny the guidance of the Holy Spirit in such difficult decisions. It is, however, to affirm that the guidance of the Holy Spirit, for the most part, takes place in such a manner that all our capabilities of cognition, analysis and evaluation are incorporated. The Holy Spirit guides us by fully involving us and thus making us responsible persons (cf. De Villiers 1978:164-174).

Should the appeal to the conviction that God Almighty is Lord over life and death rather be interpreted as the argument that only God controls and may control human life, one has to be careful not to fall in the trap of crude determinism. Such crude determinism is at work when some evangelical churches teach that the doctrine on God's special providence implies that Christians should accept with resignation everything that overcomes them, including terminal illness and unbearable suffering, as the outcome of God's will. 
The logical conclusion that they should therefore also do nothing on their side to avoid serious illness or to overcome such illness and the suffering it involves, is seldom drawn. The refusal of conservative Reformed Christians in the small town of Staphorst in the Netherlands in the sixties to inoculate their children against polio is such an example.

One can, of course, try to avoid such crude determinism by arguing that belief in the Lordship of God over life and death does not so much imply a denial of the responsibility we indeed have for our own lives and those entrusted to our care, but only the denial of any responsibility on our side to decide on such a crucial issue as when and how we or others should die. Making such a distinction does not, however, help much in a situation where medical practitioners on a daily basis make decisions that have a direct impact on when and how patients die. The decision to resuscitate a patient who had a serious heart attack could avoid her certain death at that particular point in time and could add many more happy years to her life. It could, however, also have the result that her heart starts to beat again, but she remains in a coma due to brain damage caused by a lack of oxygen during the period in which her heart stopped. If a ventilator is used to help keep the patient in the coma alive medical practitioners and family members are then again faced with the decision on whether and when the 'plug should be pulled' to bring about the death of the patient. In rare cases the patient may keep on living even after the ventilator has been unplugged. New decisions then await those involved on whether artificial nutrition should be continued or rather discontinued to allow the patient in the 'persistent vegetative state' to die of hunger and thirst. The same applies to many other cases medical practitioners have to deal with on a daily basis. The conclusion is unavoidable: we are already on a large scale taking the responsibility to decide on when and how seriously ill persons will die. And there is no reason to morally condemn those who take such a responsibility on them. The ethical issue is not so much the responsibility to decide on when and how a seriously ill patient should die, but rather whether this responsibility may include in certain circumstances the decision in favour of medically assisted suicide or voluntary euthanasia. In the context of this article the ethical issue could be defined even narrower: 'May the responsibility of the Christian to take care of his or her own life and those of other persons, include in the case of the terminally ill Christian the decision to request medically assisted suicide or euthanasia?'

\section{Autonomy is also for Christians the final arbiter in deciding}

In the previous section we have argued that the issue of the moral acceptability of medically assisted suicide and euthanasia cannot be foreclosed by appealing to an absolute prohibition based on the sixth commandment and the belief in God's Lordship over life and death. Christians cannot avoid the responsibility to thoroughly reflect and decide on the acceptability of these two practices in particular situations. Does that now, however, mean that they may elevate their own autonomy to final and sole arbiter when deciding on the matter?

In Western liberal democracies the right to autonomy plays a central role in the debate on the legalisation of medically assisted suicide and euthanasia. Autonomy as moral value to which this right relates is highly regarded as the core of human dignity, which in turn is seen as the foundational value of human rights. Although they are in the minority, a number of Christian ethicists can be found, who also argue in favour of the named practices by appealing to autonomy as central value. The Dutch theologian Harry Kuitert is a clear case in mind.

Autonomy needs not be interpreted as a synonym of arbitrary self-determination, of doing whatever you wish to do. For Immanuel Kant the autonomous legislation of the will entails the free and rational recognition of a general moral law. The autonomy of the individual is thus conditioned by the moral law, which applies to everyone (Kant 1948; cf. Körtner 2012:121-122). However, it cannot be denied that today autonomy is often understood as pure self-determination. Especially in debates on the ethical acceptability of medically assisted suicide and voluntary euthanasia protagonists of these two practices often in a rather abstract way elevate the self-determination of the patient to final arbiter. Whenever a patient wishes, for whatever reasons, to be medically assisted in suicide or in euthanasia - the argument goes - a moral obligation rests on medical practitioners and family members to grant the wish. By implication it is taken for granted that the wish of the patient is always morally acceptable.

Kuitert starts off his endorsement of the principle of selfdetermination as final arbiter when it comes to end of life issues with a number of qualifications. He asserts: 'Selfdetermination thus definitely does not mean that I only do what I wish, that no one else has a determining influence on my life, even that nobody may have such a determining influence. It rather means that there are limits to the power they have to determine my life and that I may come up for these limits' (Kuitert 1993:73, tr. from the Dutch). Kuitert is strong in emphasising that no one, including medical practitioners, may take life and death decisions on behalf of patients. In response one cannot but agree with him that when it comes to such decisions moral limits must be respected, including the moral guideline that the informed consent of the patient must be obtained. Kuitert is, however, not so strong in pointing out what the moral limits are that would prevent the patient's self-determination from deteriorating into arbitrariness, a futile attempt to retain total independence, or a panicky flight from a difficult situation. These moral limits in his opinion clearly do not come from the religious beliefs of Christians. In his discussion of the question: 'Is there anything in the Christian faith, which makes euthanasia ... impossible for Christians?' (Kuitert 1993:122, tr. from the Dutch), he comes to a negative conclusion. Christian beliefs regarding life as a gift from God and the meaning of death and suffering are, in his opinion, of no consequence when the content of such moral decisions is 
at stake. They have, at the most, a certain motivational role to play (Kuitert 1993:119-139).

I agree with Nigel Biggar that from a Christian ethical perspective it is unacceptable to equate autonomy with a selfdetermination that denies the validity of moral values that are independent of my will. ${ }^{5}$ 'In the light of Christian theology ... the peculiar value of human life lies not in the freedom to decide value, but in the freedom to acknowledge and serve the value that is given by God, both by observing the moral law and by heeding one's vocation as an individual. It lies not in sheer autonomy, but in responsibility first to God and therefore also to one's human fellows' (Biggar 2004:42-43). When it comes to deciding on the request for medically assisted suicide or euthanasia, the responsibility of Christians would include reflecting on the ethical implications of the message of the Bible and their personal vocation from God. They would also have to take into consideration the prevalent moral consensus within the Christian church and the society in which they live and consult family members and fellow Christians. And finally, they should try to ascertain to the best of their ability what the foreseen consequences of a request for medically assisted suicide or euthanasia for family members and for the moral fibre of society at large would be (cf. Bedford-Strohm 2012:45).

\section{The moral implications of relevant Christian beliefs}

The conclusion drawn in the discussion in the previous section has been that the message of the Bible does not entail an absolute prohibition against medically assisted suicide and voluntary euthanasia. However, this does not mean that Christians have to fall back on their own autonomy as highest arbiter when making decisions in this regard, as if their religious beliefs do not provide any moral guidance. Some of these beliefs do have ethical implications for their decisions on life and death, and their internalisation of these beliefs through participation in the practices and rituals of the church do cultivate in them basic moral attitudes or virtues that provide guidance when confronted with the option to request medically assisted suicide or euthanasia. In the last part of this article I am discussing the moral implications of these relevant Christian beliefs.

\section{Respect for the sacredness of human persons}

On account of the message of the Bible, Christians believe in the sacredness of human persons. Although the Bible teaches that humans have a calling to be stewards of all of God's creation and should have a certain respect for plants and animals, it certainly teaches that the respect we should have for the lives of human beings is special. This is a respect we

5.cf. for similar criticism of an abstract concept of autonomy in terms of selfdetermination Ulrich Körtner (2012:122): 'It is both philosophically and theologically problematic to, on the one hand, relate human dignity to a concept of autonomy that understands individuality in terms of autarky and complete independence, and to, on the other hand, experience every form of depending on and and needin other people as compromising the integrity of the self. Such an understanding of autonomy leads to the view that all suffering and weakness reduce the dignity of a person and that only an abstract self-determined death is in line with human dignity' (tr. from the German). should have for the lives of all persons, irrespective of their gender, race, class, age, sexual orientation, appearance or mental capacity. The reason is not that persons earn such respect on account of some admirable characteristics or some valuable contribution to society. If this were the case we would have been justified in having more respect for the lives of meritorious persons than for the lives of persons who in our opinion are less meritorious. The reason is rather that the Bible teaches that God bestows on each and every human being a special dignity or sacredness. 'The concrete person, beautiful or ugly, productive or idle, smart or stupid, is the one whom God made, whom God loves, whose life is in God's hands, and for whom his Son died on the cross. This is the person who walks humbly on the earth as the image and likeness of the Creator who made him ... (H)e is, with all his gifts and in spite of all his sins, the sacred person among all other valuable living creatures' (Smedes 1983:105).

Respect for the sacredness of persons entails a certain awe and humility which compels us to keep a certain distance, to maintain a certain circumspectness and carefulness when we are taking decisions that could impact significantly on our own lives or those of others. It is prone to cultivate in us a strong moral prejudice against the killing of human persons, including committing suicide, or requesting medically assisted suicide or euthanasia. This does not mean that this prejudice cannot be overridden by other considerations. It does, however, mean that such considerations must have more moral weight than the strong moral prejudice against the killing of human persons. Should I and the loved ones I consult not be convinced that considerations in favour of the request for medically assisted suicide or euthanasia morally outweigh the moral prejudice against killing human persons we have to refrain from it.

\section{Gratefulness for life as a gift from God}

On account of the message of the Bible, Christians believe that their lives are gifts from God. In the past, theologians and philosophers often argued that this belief entails a clearcut moral prohibition against suicide: because life is not simply our property, but a gift or a loan from God, we have no right to damage or destroy it. Against this argument the counter-argument has been made that if a gift is genuine, then the donor has relinquished his or her rights of control. If life is really a gift from God to the individual, the individual has the moral right to do with it as he or she chooses (cf. Biggar 2004:18). In my opinion both the argument and counter-argument are based on a misunderstanding of the core meaning of this Christian belief. The argument does not sufficiently take into account that a gift is only a genuine gift when it is given with no strings attached. It should especially not be equated with a loan that reduces the receiver to a debtor faced with the obligation to pay back the loan. The counter-argument does not sufficiently take into account that an attitude of 'I can do with the gift whatever I like' is not a fitting attitude for the receiver of the gift. It should rather be one of gratitude, joy and humility on account of the undeserved, unconditional nature of the gift. When the gift is 
as precious as life itself an attitude of cherishing and care is also fitting.

In his book on gratefulness the Dutch philosopher Paul van Tongeren argues that gratefulness for life should be seen as a virtue that can be cultivated, rather than as a duty we have to fulfil (Van Tongeren 2015:67-78). When we believe that life is a gift, and when we have regular experiences of life as a gift, gratefulness for what we experience in life, even for life itself, needs not be something that we only occasionally experience. It can over time develop into a disposition that, in turn, enables us to, on a more continuous basis, experience life as a gift. If the major key in which we live our lives becomes gratefulness, it is possible to even in difficult situations, when we are sick and are suffering, experience life as a gift. Van Tongeren observes that in religion and in art the experience of beauty and goodness and of thankfulness over against God in the midst of suffering and evil, has often been recorded. ${ }^{6}$ We can conclude that the moral implication of the Christian belief in life as a gift of God does not so much lie in an obligation not to make an end to life, but in its cultivation of the virtue of thankfulness that can also in the terminal stage of illness assist the patient to longer uphold a positive attitude to life and to thus fend off the need to make an end to one's life.

\section{Trust in the sustained care and support of God}

Earlier in the article I critically discussed the appeal to the Lordship of the Almighty God to ground an absolute prohibition of medically assisted suicide and voluntary euthanasia. In such an appeal the Almighty God is equated with an authoritarian ruler who jealously controls everything and everyone and leaves little room for human beings to exercise responsibility. However, the dominant picture provided by the Bible of the Almighty God is different. He is the God who restricts his own omnipotence in more than one way. He creates human beings as free beings, which also includes the freedom to choose evil and to turn against Him. He does not destroy humanity and the world in wrath when human beings rebel against Him, but rather faithfully continues to sustain his creation. He does not force human beings to leave their sinful ways, but rather appeals to them to repent their sins, and forgives them when they do so. Through the incarnation and death of his Son he identifies in the strongest possible manner with the plight of human beings and the world. He cares for the sick and the poor and promises to support them even in the hour of death. He thus exercises his rule over the world by means of the power of his love.

On Christians in the terminal phase of illness this belief in the faithful presence and support of God in their suffering can,

6. He quotes as an example a prayer of gratitude by Etty Hillesum at the deathbed of her beloved (Van Tongeren 2015:97, tr. from the Dutch):

I am so happy and so thankful and I find life

so beautiful and meaningful. Yes, beautiful and meaningful,

while I stand here at the bed of my dead friend,

who died much too young and while I am in each moment

deported to an unknown land.

My God, I am so thankful for everything. and often does, have a strong comforting and empowering impact. As the German theologian Wolfgang Huber puts is: they may trust that even in death they will not fall deeper than the hands of God (Huber 2013:273). The moral significance of trust in the sustained care and support of God when it to comes to medically assisted suicide and voluntary euthanasia thus consists in providing hope and comfort to believers and strengthening their inner resilience against death seeking despair.

\section{The responsibility to remain true to one's vocation as Christian}

Christians believe that each one of us has a unique vocation from God to fulfil in this life. One may even say that it is this unique vocation that in the first instance constitutes die dignity of the human individual. No one else in all of history can play the part that is given to me to play in the drama of the salvation of the world at this time, in this place and in this manner (cf. Biggar 2004:6). Part of this vocation is to cooperate with others, in my own way in my own profession and elsewhere, to the general improvement of all life on earth. Part of it is also to witness in my example and deeds to the biblical message of God's salvation of the world in Jesus Christ.

It is, of course, true that in the terminal phase of illness we are not to the same extent in a position to actively fulfil this vocation as when we are healthy. This does not take away our responsibility to fulfil our vocation as Christians. 'For responsible life can take passive as well as active forms; or, more exactly; it can take active forms that are more receptive and appreciative than assertive. We are still responsible subjects even when we are not asserting ourselves by trying to fulfil a desire ..., make a decision, or engage in a project. We are still responsible subjects even when we are not in control, when we are helpless, when life is less something we 'have' than something that happens to us. We still affirm and promote the good of human friendship when we receive the love and care of others, and even when we have no choice but to receive. And, besides, in receiving another's love we affirm it, and in affirming it we ourselves give love' (Biggar 2004:45).

Michael Banner is of the opinion that there is a need in our day to revisit the Ars moriendi texts that were influential in the church of the Middle Ages and were used to guide Christians in the art of dying. The longest chapter in the Ars moriendi texts is chapter two, which treats the temptations to which the dying are prey and the virtues that are remedies against them. The dying man is also bidden to take Christ as a practical exemplar. The Ars moriendi tradition in this regard relates to the tradition of the Seven Words from the cross. In those Seven Words, Christ forgives, exhorts, and sustains the other in need, commends his spirit to God, and entrusts his mother Mary to his beloved disciple, her new son, and this beloved disciple to Mary, the disciple's new mother. 'These seven words amount to a care of the self and other going beyond a mere Stoic patience to a more fully realised ideal of moral agency in death, 
notwithstanding its pains. And it was this settling of spiritual, moral, and social affairs (with God and neighbour) which was paradigmatic for the Ars moriendi tradition' (Banner 2014:113). The Ars moriendi tradition can, of course, not be retrieved in our day without significant reinterpretation and adaptation. One may, however, ask whether the introduction of updated Ars moriendi texts and practices, which are theologically and psychologically well founded, could not significantly contribute to better guidance and preparation of present Christians in approaching their own death and strengthening their moral agency in death.

\section{Concluding remarks}

The moral thrust of the Christian beliefs discussed in the previous section consists, firstly, in encouraging and empowering terminally sick Christian believers to continue living a morally responsible life and, secondly, in cultivating a strong moral prejudice against requesting medically assisted suicide or euthanasia. Having a strong moral prejudice is, however, not the same as being confronted with an absolute moral prohibition. A strong moral prejudice can, in principle, be overridden by weightier moral considerations.

Which moral considerations in favour of medically assisted suicide or euthanasia could outweigh the moral prejudice against these two practices? In my opinion these are the two most important considerations.

- The suffering experienced by the terminally ill patient must be unbearable. Both the terminally ill patient and the medical practitioners involved must testify that this is the case.

- Other morally more acceptable means to relieve the unbearable suffering, or to at least make the suffering more bearable, must have been explored, but proven to be unsuccessful or not available.

The moral right of a terminally ill patient to request the relief of unbearable suffering needs not be argued here. What needs to be argued is rather the second consideration. From the perspective of Christian ethics the introduction of palliative care for terminally ill patients and the establishment of hospices specialising in the administration of palliative care, can be strongly commended. Where curative medical care has the cure of patients as aim, palliative care has the effective relief of bodily, psychological and spiritual pain and suffering as aim. It is claimed that palliative care can today effectively relieve the suffering of $95 \%$ of all terminally ill patients (cf. Badham 2009:12). From a moral perspective seeking and obtaining effective and adequate relief from suffering is indeed preferable to requesting medically assisted suicide or euthanasia. It should therefore be the first and preferred option for suffering terminally ill patients.

In certain circumstances another morally preferable means is the termination of curative medical care. When medical practitioners involved agree that the application of curative medical care has become useless or excessively burdensome there is no moral justification for proceeding with it, even when the outcome of the termination is that the terminally ill person dies more quickly (cf. Meilaender 1996:71-72). This is, for example, the case when a terminally ill cancer patient who suffers unbearably, voluntarily chooses not to undergo a third round of chemical treatment, or refuses to take antibiotics when she protracts serious pneumonia. She cannot be morally blamed for choosing this way to die a quicker death to escape unbearable suffering, as she is only allowing a serious illness to take its course.

This still leaves us with the question: May a terminally ill Christian who is suffering unbearably request medically assisted suicide or euthanasia when palliative care proves to be ineffective, or the termination of curative medical care does not provide a way out of the unbearable situation? I am of the opinion that there are exceptional situations in which such a request, as well as granting the request, might be morally justified. The decision on exactly when such a request is morally justified is not one that should be made by outsiders. It should rather be left to the patient herself, her next of kin and the medical professionals involved. They are the only persons who know the situation well enough and are in a position to responsibly weigh up all the relevant factors.

The implication of what I am saying is, of course, that medically assisted suicide and voluntary euthanasia should be legalised, be it that strict conditions should apply to avoid the danger of a slippery slope resulting in the legal permission of morally dubious practices. What the conditions should be for legalisation is an important issue that merits a thorough discussion on its own.

\section{Acknowledgements Competing interests}

The author declares that he has no financial or personal relationships which may have inappropriately influenced him in writing this article.

\section{References}

Augustine, A., 2004, 'The city of God', in P. Scaff (ed.), Nicene and post-Nicene fathers, vol. 5, Hendrickson Publishers, Peabody, MA.

Badham, P., 2009, Is there a Christian case for assisted dying? Voluntary euthanasia reassessed, SPCK, London.

Banner, M., 2014, The ethics of everyday life: Moral theology, social anthropology, and the imagination of the human, University Press, Oxford.

Bedford-Strohm, H., 2012, 'Verantwortlich mit dem Leben umgehen: Zur Diskussion um die Sterbehilfe', in M. Friess (Hg.), Wie sterben? Zur Selbstbestimmung am Lebensende: Eine Debatte, pp. 140-151, Gütersloher Verlagshaus.

Biggar, N., 2004, Aiming to kill: The ethics of suicide and euthanasia, Darton Longman, London.

De Villiers, D.E., 1978, Die eiesoortigheid van die Christelike geloof, Rodopi, Amsterdam.

De Villiers, D.E., 2012, 'Reflecting on the distinctiveness of Christian morality after thirty years', Verbum et Ecclesia 33(2) Art. \#758.

Friess, M., 2012a, 'Aspekte der Sterbehilfedebatte - Eine Einführung', in idem (Hg.), pp. 7-38.

Friess, M. (Hg.), 2012b, Wie sterben? Zur Selbstbestimmung am Lebensende: Eine Debatte, Gütersloher Verlagshaus.

Hauerwas, S., 1974 (1984), Vision and virtue: Essays in Christian ethical reflection, University Press, Notre Dame. 
Hauerwas, S., 1981, A community of character: Toward a constructive Christian social ethic, University Press, Notre Dame.

Hauerwas, S., 1983, The peaceable kingdom: A primer in Christian ethics, University Press, Notre Dame.

Huber, W., 2013, Ethik: Die Grundfragen unseres Lebens von der Geburt bis zum Tod, $\mathrm{CH}$ Beck, Münich.

Kant, I., 1948, The moral law: Groundwork of the metaphysics of morals, transl. H.J. Paton, Routledge, London.

Körtner, U.H.J., 2012, 'Recht auf Leben - Recht auf Sterben: Autonomie am Lebensende und ihre Grenzen', in M. Friess (Hg.), pp. 120-139.

Kuitert, H.M., 1993, Mag er een eind komen aan het bittere einde? Levensbeëindiging in de context van stervensbegeleiding, Ten Have, Baarn.
MacIntyre, A., 1984, After virtue: A study in moral theory, University Press, Notre Dame. Meilaender, G., 1996, Bioethics. A primer for Christians, Eerdmans, Grand Rapids, MI. Smedes, L.B., 1983, Mere morality: What God expects from ordinary people, Eerdmans, Grand Rapids, MI.

Stout, J., 1988, Ethics after Bable: The languages of morals and their discontents, Beacon Press, Boston, MA.

Van Tongeren, P., 2015, Dankbaar: Denken over danken na de dood van God, Uitgeverij Klement, Zoetermeer.

Weber, M., 1994, 'The profession and vocation of politics', in P. Lassmann \& R. Speirs (eds.), Weber: Political writings, pp. 309-369, University Press, Cambridge.

Whimster, S. (ed.), 2004, The essential Weber: A reader, Routledge, London. 